children. The pupils' interactions with one another are observed and they are taught on the spot to identify their own feelings and those of others, to restrain themselves, to delay gratification and to reduce stress: indeed, the only desirable quality on which no instruction is provided is a sense of humour, but that may be lacking in their earnest teachers. Outcome studies on these schools have apparently all been favourable, but Goleman does not give enough information to make it possible to judge them. Were the results significant? How long did the effects of the teaching last? Were the assessors blind to the treatment the children had received? Were there placebo groups to control for the Hawthorne effect - the tendency for any intervention to improve matters?

Despite these omissions and despite his selective use of evidence, Goleman has written an interesting if somewhat naive book. He has done his homework well, describing many recent studies, although he ignores older work such as that of Stanley Schachter. Some will find the journalistic tone repugnant, but anyone interested in emotion is likely to discover challenging new ideas in this book: it should be read by social workers and agony aunts everywhere.

Stuart Sutherland is at the Laboratory for Experimental Psychology, University of Sussex, Brighton BN1 9QG, UK.

\title{
Geological controversies hammered out
}

\author{
Nicolaas Rupke
}

\begin{abstract}
Murchison in Moray: A Geologist on Home Ground. With the Correspondence of Roderick Impey Murchison and the Rev. Dr George Gordon of Birnie. By Michael Collie and John Diemer. American Philosophical Society: 1995. Pp. 263. $\$ 20$ (pbk).
\end{abstract}

ONE of the great and intricate constructs of modern science is the stratigraphic table, which comprises the time-rock units of geological history. The table acquired its nearly definitive form during the first half of the nineteenth century. Among the leading stratigraphers of the period was Roderick Impey Murchison (1792-1871), whose most famous publication, The Silurian System (1839; republished under the title Siluria in 1854, 1859 and 1867), was an important contribution to the construction of the Palaeozoic era (and erathem). Part of the fieldwork for this book was carried out in the north of Scotland, along the Moray Firth, northeast of Inverness. Here, in the Elgin area, a controversy developed over the stratigraphic position of rocks, which Murchison believed to be old red sandstone, but which proved to be new red (PermoTriassic). One source of Murchison's information, in particular for the fourth edition of his great book, was a local clergyman-naturalist, George Gordon, who had a thorough knowledge of the geological structure of the region. The Murchison-Gordon correspondence, from 1858 to 1867 , forms the second part of Murchison in Moray. In editing these letters, Michael Collie and John Diemer have made a valuable contribution to Murchison scholarship.

Murchison was, however, far more than a leading stratigrapher. He was a member of the magic circle of gentlemennaturalists who ruled British science dur- ing the Victorian era; he became directorgeneral of the British Geological Survey; he carried out expeditions to Russia; and he was one of the founders of the Geographical Society, and enthusiastically supported explorations and surveys in the context of British colonial expansion. The imperial dimension of Murchison's activities has been discussed by James Secord and, in more detail, by Robert Stafford, who entitled his biography of Murchison Scientist of Empire (1989). Moreover, as Martin Rudwick long ago pointed out,

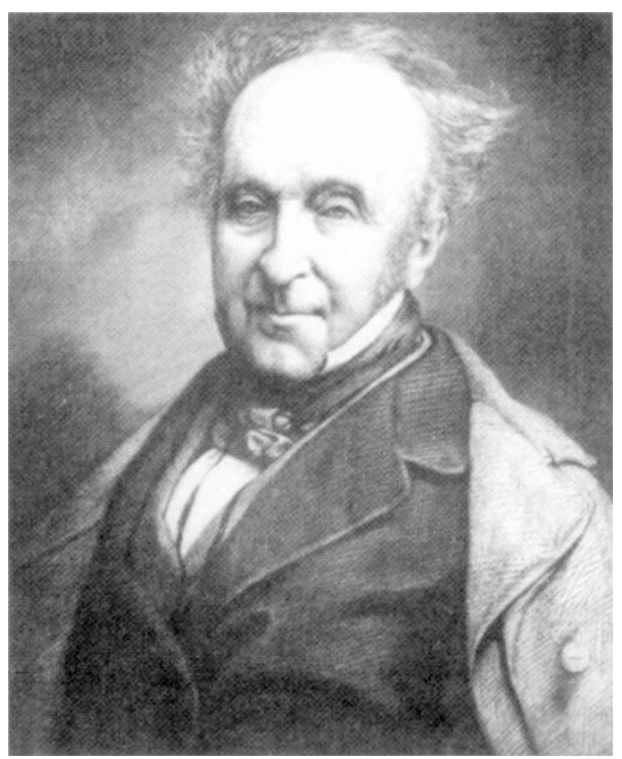

Roderick Impey Murchison: scientist of Empire.

Murchison, who began his career as a military man, had a disposition to turning scientific controversies into "paramilitary campaigns" against his adversaries, such as T. H. de la Beche (over the delineation of the Devonian system) and Adam Sedgwick (over the Cambrian/Silurian).

Such assessments of their hero are anathemas to Collie and Diemer, and the first part of their book is designed to present a very different Murchison. To them, interpreting Murchison in the context of his career objectives and of the political dynamics of his metropolitan social circle is nothing less than sullying the character and reputation of an upright Scotsman and an honourable geologist. The authors sternly censure "the ease with which some university-based critics stigmatize and condemn Murchison, sneering at him whenever the opportunity presents itself". In places, Collie and Diemer get hot under the collar defending Murchison against both his Victorian and present-day detractors. The latter are rapped over the knuckles for being "retrospective mythmakers". Stafford is the blackest of their bêtes noires, and one of his complaints about Murchison, namely that he engaged in élitist socializing in his London home, is countered as follows: "Actually, the criticism of Murchison's establishment in Belgrave Square was John Ruskin's, a person whose egotism and mean-mindedness were amply supported by a private income derived from the sale of sherry. Perhaps not enough sherry was consumed at a Murchison soiree."

The proper historiographical treatment of Murchison requires, in the view of the authors, stepping into his shoes, retracing his footsteps in the field and facing the technical geological problems he encountered. To this end, they use, in addition to Murchison's publications, the Gordon correspondence and also his notebooks the latter in preference to the journal he wrote towards the end of his life, criticizing along the way David Oldroyd for having given pride of place, in The Highlands Controversy (1990), to the journal rather than the notebooks.

There is no doubt that the authors have done a fine and valuable job in following Murchison into the Moray Firth region. Yet their historiographical approach is atavistic, carrying us back to a time when the history of science was for the larger part written by failed or retired scientists. Although their spirited attack on recent Murchison scholarship adds spice to the narrative, the authors might have done better to look for ways of integrating their solid, detailed work with the wider-ranging efforts of previous Murchison studies. The possibility of such an integration is indicated by their own conclusion: "Thus what seemed to be a straightforward argument about the interpretation of geological and palaeontological evidence was in fact ideologically complex and interesting”. $\square$

Nicolaas Rupke is at the Institut für Geschichte der Medizin, Georg-AugustUniversität, Humboldtallee 36, D-37073 Göttingen, Germany. 